\title{
Cropping Systems and Land Use in Sylhet Region
}

\author{
M A Muttaleb ${ }^{1 *}$, S M Shahidullah ${ }^{1}$, M Nasim ${ }^{1}$ and A Saha ${ }^{1}$
}

\begin{abstract}
Towards the sustainable food security for a particular area, the policymakers, researchers, extension and development agents need the detailed information of cropping patterns, cropping intensity and crop diversity. Sylhet, a potential region of enormous potentiality of growing crops across the haor area lying below the northeastern Himalyan foothills experience the highest rainfall in the world to make the basin prone to flashflood. That is why, a study was conducted in the region considering all the upazillas during 2016 using the pretested semi-structured questionnaire and validated by appropriate informants with a view to documenting the existing cropping patterns, cropping intensity and crop diversity in the region. As per the study the region is dominated by the rice based cropping pattern. The non-rice based cropping pattern are either few or the area under those cropping patterns are not enough to satisfy the non-rice food requirement of people of the region. Beside these, the cropping patterns and crop diversity appeared as below the expected level. Therefore, much thrust is needed to initiate research and development activities to diversify the single or double-cropped cropping pattern with the introduction of appropriate crops and crop varieties even other non-crop agricultural commodities.
\end{abstract}

Key words: Cropping pattern, land use intensity, diversity index and Sylhet basin

\section{INTRODUCTION}

The cropping pattern is an important indicator of agricultural land use. It has implications for agricultural growth in general and livelihood improvement of the millions of farmers. Environmental or Agro-ecological conditions, and related risks or relative advantages are the main determinants of cropping pattern along with several socioeconomic factors (Mandal and Bezbaruah, 2013). Available data on total available arable lands of the country is not conclusive and seem to be varied due to the methodology and timeframe followed by the organizations (Hasan et al., 2013). Statistics on the conversion rate of agricultural lands to nonagricultural activities also vary with the studies, i.e. an annual change of about $0.13 \%$ (Rahman and Hasan, 2003) or $0.27 \%$ between the years of 1976-77 and 2010-11 (BBS 2011). Furthermore, climate change showed recurrent floods, droughts and unpredicted rainfall patterns that worsen the existing pressure on land, water and natural resources (Shirsath, 2017). Sylhet agricultural region is a complex region with a multitude of diverse micro-environments (FAO, 1988) with variable landscape ranged from hills to very lowlands. This region is consists of six dominant agroecological zones namely, Old Meghna Estuarine Floodplain, Eastern SurmaKusiyara Floodplain, Sylhet Basin, Northern and Eastern Piedmont Plains, Northern and Eastern Hills and Akhaura Terrace (FAO, 1988). The yearly decreasing trend of cropland was 3,122 ha (0.33\%) during 1976-2010 in Sylhet division (Hasan et al., 2013). Cropping intensity of Sylhet agricultural region is almost stagnant for last two decades (BBS 2011, 2014, 2015) even though agriculture is the main source of income of farmers (Banglapedia, 2004). The rapid increase in human population creates additional pressure on natural resources at above optimal levels of their inherent potential, which resulted in the loss of biodiversity, serious soil erosion leading to depletion of plant nutrient, gradual degradation and decline in productivity and carrying capacity, etc (Borthakur et al., 1998). Even though appropriate cropping

${ }^{1}$ Rice Farming Systems Division, BRRI, Gazipur 1701; *Corresponding author's E-mail: a.muttalebrfs@gmail.com 
patterns may facilitate maximum possible land utilization as well as efficient use of other scarce resources in a sustainable manner. Diversified cropping pattern may be the option for the farmers as a coping strategy against different risks (Mandal and Bezbaruah, 2013). Typology of different cropping systems is the base for the managers of these systems to intensify production (Shriar, 2000). Hence, judicious and appropriate use of limited resources in the case of intervention selection that does not lead to increased mal adoption or inequity in the society over the long term. Existing trends of available agricultural lands is an essential requirement for any land use planning related to farming and food security in a sustainable manner. Therefore, an increased understanding of arable land use based on the cropping systems, patterns along with diversity are very essential for the appropriate intervention in a sustainable way. But very few studies are available related to cropping systems and patterns. In this context, existing cropping patterns along with their diversity of such complex agricultural region are very crucial to minimize risk and to improve overall crop productivity. Accordingly, the present study was designed with the following objectives to:

- Build up a database on major existing cropping patterns in the Sylhet region

- Determine the crop diversity at the local and the regional level.

\section{METHODOLOGY}

Thirty-eight upazilas of Sylhet, Sunamganj, Habiganj and Maulvibazar district under Sylhet agricultural region were the locale of this study. Data were collected using double stage procedure through semistructured questionnaire. At the initial stage, data were collected through pre-tested semi-structured questionnaire from 38 pre-assigned SubAssistant Agriculture Officers (SAAO) of each upazila during September 2016 at upazila level. The SAAOs were purposively selected by Agriculture Extension Officer
(AEO) or Additional Agriculture Officer (AAO) or Upazila Agriculture Officer (UAO)or their united decision. Prior to data collection, the pre-tested questionnaire was explained along with proper guidelines to the AEOs or UAOs or both and handed over to them at each Deputy Director's office of Directorate of Agricultural Extension (DAE) during monthly meeting for the sake of accurate data collection. The filled questionnaires were collected, checked and analyzed to find the inconsistencies of the supplied data before validation workshop. All the inconsistencies among the information were documented. Second stage of data collection was a daylong data validation workshop at district level during 23 to 26 October 2016. Participants of validation workshop were one SAPPO and three SAAOs experienced and engaged in crop-based data documentation, all officers from all upazilas viz UAOs, AEOs, AAEOs, DD (DAE), DD (Horticulture), DD of Seed Certification Agency, DTO and ADDs, one representative from Agricultural Training Institute (ATI) and scientists of BRRI regional station, Habiganj. The number of participants of validation workshop ranged from 59 to 88 . All the participants were divided into three to four groups for data validation. Each group was facilitated by two RFSD scientists. After thorough discussion on collected data along with documented inconsistencies by each group, authenticated data were captured. Crop diversity index was calculated by using the following equation described by Kshirsagar et al. (1997).

$$
C D I_{i}=1-\sum_{j=o}^{n}\left(\frac{a_{i j}}{A_{i}}\right)^{2}
$$

Where, $\mathrm{CDI}_{\mathrm{i}}=$ Crop Diversity Index $a_{i j}=$ Area planted to the $j^{\text {th }}$ crop in the $\mathrm{i}^{\text {th }}$ location

$A_{i}=$ Total area planted under all crops

The index is zero for a land area growing only one crop. It approaches unity as the level of diversity increases. Compilation and processing of collected data were done using Micro Soft Excel programme. Descriptive 
statistics were used to facilitate the presentation of the findings.

\section{RESULTS AND DISCUSSION}

\section{Land use}

Table 1 presents the status of agricultural land utilization. The net cropped area of the Sylhet region is 773,480 ha. Crops occupied the particular land for around the year were considered under annual crops. Crops that completed life span within one year were regarded as annual crops (Martin and Leonard, 1953). The major annual crops reported in the region were pineapple, sugarcane, banana, papaya, betel leaf, ginger and turmeric. The coverage of annual crops varied from zero to 1,040 ha accounted to only $0.60 \%$ of the net cropped area (NCA) in the region. The coverage was exclusively poor compared to those of the other crops due to the mal-adjustment with the land type and climatic conditions. The annual erratic and uneven distribution of rainfall is responsible for the varying intensities of flood from the natural to the extreme (flash flood in March-April). At a glance, the region possesses $57 \%$ single cropped area (SCA), 37\% double cropped area (DCA), 6\% triple cropped area (TCA). All the upazilas were dominated by SCA followed by DCA except three upazilas (Table 1). These type of cropping patterns are due to the availability of adequate water or excess water that does not permit cultivation of more crops in this region. Another cause may be conservativeness of absentee landowner. Mean cropping intensity of Sylhet region was $148 \%$. According to BBS cropping intensity of Sylhet agricultural region is almost stagnant at around $150 \%$ for last few decades and much lower than the national average $192 \%$. The area that could not be defined under SCA, DCA, TCA or QCA was considered as others whose coverage is less than $1 \%$ of the NCA. An overwhelming majority of single or double cropping pattern with exclusive rice due to land type and class along with the environmental and climatic factors that is unsuitable for non-rice crops (FAO, 1988).

\section{Cropping patterns of Sylhet}

In total 87 cropping patterns were observed in Sylhet region of which eight cropping patterns with exclusive rice crop covers over $90 \%$ of the NCA. There were 21 cropping patterns with exclusive non-rice crops covering over $2 \%$ of the NCA. Rest of the NCA i.e. around $8 \%$ area is covered by 58 rice - non-rice cropping patterns (Appendix 1).

\section{Rice and non-rice crops at a glance}

Table 2 presents eight cropping patterns where rice is the only crop round the year. It comprises $90.24 \%$ of the NCA in the region. Among them, single rice, double rice and triple rice areas are $56 \%, 28 \%$ and $2 \%$, respectively. It reflects the unparallel dominance of rice in the cropping systems in Sylhet region. According to FAO (1988), modern and local rice varieties are the main crop in medium lowland and lowland in this region. In case of individual pattern single Boro i.e. Boro-Fallow-Fallow has the highest coverage $(39.64 \%)$ and was recorded in 36 upazilas out of 38 upazilas. The second dominant pattern Boro-Fallow-T. Aman occupied $15.74 \%$ of NCA which was reported in 37 upazilas. Single T. Aman i.e. FallowFallow-T. Aman covered third highest area $(15.29 \%)$ with its existence in only 30 upazilas. Another important pattern Fallow-Aus-T. Aman found in 29 upazilas with the fourth position $(12.62 \%)$ in respect of area coverage. Thus, the overwhelming majority $(90.24 \%)$ is under exclusive rice systems. The dominance of exclusive rice-based cropping systems is due to lion share of land under medium and lowland ecosystems where recession of floodwater usually delayed. This situation is also worsened by high rainfall. Ultimately, soils of this region remain wet most of the time due to the cumulative effect of these factors. In this circumstance, soils of this region are more suitable for wetland crops than for dryland crops in Kharif season. The delayed recession of floodwater tends to delay the establishment of dryland Rabi crops until after the optimum date (FAO, 1988). Farmers of Tripura state of India have been following rice-rice systems from centuries in India due to food habit and agro-climatic situations (Anup et al., 2015). 
Table 1. Land use of different upazilas in Sylhet region (area in hectare), 2014-15.

\begin{tabular}{|c|c|c|c|c|c|c|c|c|c|c|}
\hline & Upazila & $\begin{array}{l}\text { Area of } \\
\text { upazila }\end{array}$ & $\begin{array}{r}\text { Annual } \\
\text { crop }\end{array}$ & SCA & DCA & TCA & QCA & Other & NCA & C.I. $(\%)$ \\
\hline 01 & Ajmiriganj & 22400 & 0 & 10850 & 4550 & 0 & 0 & 100 & 15500 & 130 \\
\hline 02 & Bahubal & 30100 & 550 & 5900 & 8100 & 1800 & 0 & 100 & 16450 & 172 \\
\hline 03 & Baniachang & 48246 & 0 & 22960 & 14320 & 50 & 0 & 170 & 37500 & 139 \\
\hline 04 & Chunarughat & 42696 & 310 & 460 & 13500 & 8160 & 0 & 180 & 22610 & 233 \\
\hline 05 & Habiganj & 25139 & 180 & 4000 & 9010 & 6400 & 0 & 140 & 19730 & 211 \\
\hline 06 & Lakhai & 19042 & 10 & 8360 & 6815 & 205 & 0 & 120 & 15510 & 147 \\
\hline 07 & Madhabpur & 22427 & 140 & 0 & 11070 & 4800 & 0 & 130 & 16140 & 229 \\
\hline 08 & Nabiganj & 30262 & 10 & 18820 & 5795 & 200 & 0 & 185 & 25010 & 125 \\
\hline 09 & Barlekha & 44905 & 450 & 5215 & 5225 & 655 & 0 & 105 & 11650 & 157 \\
\hline 10 & Juri & 18630 & 70 & 3550 & 5695 & 1140 & 0 & 115 & 10570 & 176 \\
\hline 11 & Kamalganj & 48526 & 620 & 1850 & 13070 & 2390 & 0 & 140 & 18070 & 200 \\
\hline 12 & Kulaura & 54500 & 70 & 12000 & 7030 & 3220 & 0 & 100 & 22420 & 160 \\
\hline 13 & Maulvibazar & 34419 & 60 & 14700 & 10350 & 360 & 0 & 90 & 25560 & 143 \\
\hline 14 & Rajnagar & 33815 & 100 & 8010 & 11870 & 160 & 0 & 160 & 20300 & 161 \\
\hline 15 & Sreemangal & 45093 & 450 & 3600 & 13030 & 1710 & 0 & 110 & 18900 & 188 \\
\hline 16 & Biswambarpur & 24900 & 150 & 8000 & 8630 & 175 & 0 & 95 & 17050 & 153 \\
\hline 17 & Chhatak & 44067 & 10 & 16530 & 3300 & 0 & 0 & 70 & 19910 & 117 \\
\hline 18 & Dharampasha & 53123 & 100 & 30910 & 3750 & 550 & 0 & 190 & 35500 & 114 \\
\hline 19 & Derai & 42093 & 0 & 28470 & 2250 & 0 & 0 & 80 & 30800 & 107 \\
\hline 20 & Dowarabazar & 28492 & 70 & 13615 & 7700 & 1055 & 0 & 130 & 22570 & 144 \\
\hline 21 & Jagannathpur & 37591 & 80 & 24600 & 2230 & 550 & 0 & 70 & 27530 & 112 \\
\hline 22 & Jamalganj & 30938 & 10 & 21320 & 4280 & 0 & 0 & 100 & 25710 & 117 \\
\hline 23 & Sulla & 26085 & 0 & 17150 & 6020 & 0 & 0 & 130 & 23300 & 126 \\
\hline 24 & Sunamganj South & 30317 & 10 & 21000 & 2090 & 0 & 0 & 110 & 23210 & 109 \\
\hline 25 & Sunamganj & 29083 & 10 & 10500 & 7430 & 930 & 0 & 40 & 18910 & 149 \\
\hline 26 & Tahirpur & 31425 & 70 & 14710 & 7720 & 300 & 0 & 120 & 22920 & 136 \\
\hline 27 & Balaganj & 37592 & 0 & 13900 & 12500 & 1100 & 0 & 150 & 27650 & 153 \\
\hline 28 & Beanibazar & 25072 & 0 & 9300 & 4300 & 200 & 0 & 150 & 13950 & 134 \\
\hline 29 & Biswanath & 21450 & 0 & 7300 & 7800 & 1300 & 0 & 150 & 16550 & 163 \\
\hline 30 & Companiganj & 27803 & 10 & 12235 & 5575 & 785 & 0 & 105 & 18710 & 138 \\
\hline 31 & Fenchuganj & 11480 & 0 & 5400 & 2750 & 200 & 0 & 150 & 8500 & 138 \\
\hline 32 & Goainghat & 48273 & 10 & 15000 & 6800 & 1850 & 0 & 150 & 23810 & 144 \\
\hline 33 & Golapganj & 27355 & 10 & 4900 & 11500 & 200 & 0 & 100 & 16710 & 172 \\
\hline 34 & Jaintapur & 17883 & 1040 & 7010 & 5665 & 650 & 0 & 125 & 14490 & 148 \\
\hline 35 & Zakiganj & 26955 & 10 & 13660 & 5480 & 520 & 0 & 140 & 19810 & 133 \\
\hline 36 & Kanaighat & 41225 & 10 & 11745 & 10110 & 1200 & 0 & 145 & 23210 & 154 \\
\hline 37 & Surma & 19449 & 0 & 6400 & 8500 & 0 & 0 & 150 & 15050 & 157 \\
\hline \multirow[t]{2}{*}{38} & Sylhet & 30570 & 10 & 3500 & 7140 & 950 & 0 & 110 & 11710 & 178 \\
\hline & Sylhet region & - & 4630 & 437430 & 282950 & 43765 & 0 & 4705 & 773480 & 148 \\
\hline
\end{tabular}

Table 2. Cropping patterns with exclusive rice in Sylhet region, 2014-15.

\begin{tabular}{llrrr}
\hline & Cropping pattern & Area (ha) & \% of NCA & Frequency (no. of upazila) \\
\hline 1 & Boro-Fallow-Fallow & 304800 & 39.64 & 36 \\
2 & Boro-Fallow- T. Aman & 121020 & 15.74 & 37 \\
3 & Fallow -Fallow- T. Aman & 117560 & 15.29 & 30 \\
4 & Fallow-Aus- T. Aman & 97055 & 12.62 & 29 \\
5 & Boro-B.Aman & 23830 & 3.10 & 11 \\
6 & Boro-Aus- T. Aman & 17840 & 2.32 & 12 \\
7 & Fallow- B.Aman & 10140 & 1.32 & 15 \\
8 & Boro-Aus-Fallow & 1600 & 0.21 & 2 \\
\hline & Total & 693845 & 90.24 & - \\
\hline
\end{tabular}


In the current investigation, 21 cropping patterns were identified that was free from rice (Table 3 ). The aggregate of 21 patterns has had only $2.44 \%$ of NCA. In critical comparison, it is clear that exclusive rice area is about 37 folds of the exclusive non-rice area. Among these 21 patterns, vegetable production system has the highest coverage that practised on or around the homestead area. Very limited lands are available for Rabi crops cultivation in this region (FAO, 1988). Cropping pattern diversification cannot be a risk minimization strategy in the Tripura state of India even though it clearly helps farmers to raise their farm income (Mandal and Bezbaruah, 2013). Anup et al. (2015) reported that about 15-20\% land under different vegetables like colocasia, okra, amaranthus, brinjal, cucurbits, etc are grown in during rainy season and potato, sweet gourd, cole crops, leafy vegetables etc are grown during winter season on medium upland adjacent to rice fields in the Indian state of Tripura.

\section{Boro/Haor ecosystem}

\section{Deepwater rice ecosystem}

Deepwater is a special type of ecosystem in the country. In the context of Sylhet region, this ecosystem represents a considerable portion. Table 4 presents the cropping patterns under deep water ecosystem. Among the listed 13 patterns Boro-B. Aman cropping pattern covers the largest area of 23,830 ha which represents $3.08 \%$ of the region's NCA. This pattern is distributed over 11 upazilas out of 38 . The second highest Fallow-B. Aman cropping pattern covers 10,140 hectares and distributed over 15 upazilas. The first two patterns jointly covered $4.39 \%$ NCA which is more than fourfifths of the total deep-water rice area in the region. The water level of this ecosystem ranges between 150 and $400 \mathrm{~cm}$, and water usually remains 3-4 months. Special rice varieties known as 'floating rice' are planted in these areas. In past Bangladesh had a land coverage of 3 million hectares for deepwater rice (Jackson et al., 1972). In course of time, the continuous effort on modern agriculture shifted DWR area mainly to modern Boro. Now the area under deepwater rice in Bangladesh is reduced to 0.4 million hectares (Nasim et al., 2017). Though this cropping system is less productive than other modern cropping systems, the specific fragile ecosystem still struggling because of no other alternatives.

\section{Vegetables and spices crops}

Fifty-one cropping patterns were identified for vegetables and spices crops covering an area of 60,810 ha which represents $7.86 \%$ of the NCA in the region (Table 6). Potato and other vegetables of Rabi, Kharif-I and Kharif-II; Spices

Table 3. Cropping patterns with exclusive non-rice in Sylhet region, 2014-15.

\begin{tabular}{rlrcc}
\hline & Cropping pattern & Area (ha) & \% of NCA & Frequency (no. of upazila) \\
\hline 01 & Vegetab-Vegetab-Fallow & 5890 & 0.76 & 19 \\
02 & Vegetab-Vegetab-Vegetab & 5395 & 0.70 & 16 \\
03 & Vegetab-Fallow-Fallow & 5370 & 0.69 & 14 \\
04 & Chilli-Fallow-Fallow & 735 & 0.10 & 10 \\
05 & Coriander-Fallow-Fallow & 265 & 0.03 & 7 \\
06 & Fallow-Fallow-Blackgram & 200 & 0.03 & 3 \\
07 & S.Potato-Fallow-Fallow & 180 & 0.02 & 4 \\
08 & Potato-Jute-Fallow & 150 & 0.02 & 1 \\
09 & Groundnut-Fallow-Fallow & 115 & 0.01 & 4 \\
10 & Mustard-Fallow-Fallow & 100 & 0.01 & 2 \\
11 & Vegetab-Fallow-Blackgram & 70 & 0.01 & 2 \\
12 & Coriander-Vegetab-Fallow & 60 & 0.01 & 3 \\
13 & Chilli-Vegetab-Fallow & 55 & 0.01 & 1 \\
14 & Wheat-Vegetab-Vegetab & 50 & 0.01 & 1 \\
$15-21$ & Other seven patterns (in Table 7) & 85 & 0.01 & 2.44 \\
\hline
\end{tabular}


Table 4. Cropping patterns under deep water rice ecosystem in Sylhet region, 2014-15.

\begin{tabular}{llrrr}
\hline & Cropping pattern & Area (ha) & \% of NCA & Frequency (no. of upazila) \\
\hline 01 & Boro-B.Aman & 23830 & 3.08 & 11 \\
02 & Fallow-B.Aman & 10140 & 1.31 & 15 \\
03 & Mustard-B.Aman & 2690 & 0.35 & 4 \\
04 & Wheat-B.Aman & 435 & 0.06 & 3 \\
05 & Vegetab-B.Aman & 200 & 0.03 & 1 \\
06 & Coriander-B.Aman & 120 & 0.02 & 1 \\
07 & Blackgram-B.Aman & 110 & 0.01 & 3 \\
08 & Chilli-B.Aman & 80 & 0.01 & 1 \\
09 & Lentil-B.Aman & 70 & 0.01 & 1 \\
10 & Potato-B.Aman & 70 & 0.01 & 1 \\
11 & S.Potato-B.Aman & 30 & 0.00 & 1 \\
12 & Grasspea-B.Aman & 25 & 0.00 & 1 \\
13 & Onion-B.Aman & 10 & 0.00 & 1 \\
\hline
\end{tabular}

Table 5. Cropping patterns with pulses and oil-seed crops in Sylhet region, 2014-15.

\begin{tabular}{|c|c|c|c|c|}
\hline & Cropping pattern & Area (ha) & $\%$ of NCA & Frequency (no. of upazila) \\
\hline 01 & Mustard-B.Aman & 2690 & 0.35 & 4 \\
\hline 02 & Groundnut-Fallow- T. Aman & 1245 & 0.16 & 4 \\
\hline 03 & Mustard-Fallow- T. Aman & 950 & 0.12 & 11 \\
\hline 04 & Vegetab-Groundnut- T. Aman & 800 & 0.10 & 1 \\
\hline 05 & Mustard-Boro- T. Aman & 560 & 0.07 & 4 \\
\hline 06 & Mustard-Aus- T. Aman & 510 & 0.07 & 6 \\
\hline 07 & Mustard-Boro-Fallow & 340 & 0.04 & 4 \\
\hline 08 & Fallow-Fallow-Blackgram & 200 & 0.03 & 3 \\
\hline 09 & Mustard-Jute- T. Aman & 200 & 0.03 & 1 \\
\hline 10 & Mustard-Aus-Fallow & 140 & 0.02 & 4 \\
\hline 11 & Groundnut-Fallow-Fallow & 115 & 0.01 & 4 \\
\hline 12 & Blackgram-B.Aman & 110 & 0.01 & 3 \\
\hline 13 & Lentil-Jute- T. Aman & 100 & 0.01 & 1 \\
\hline 14 & Mustard-Fallow-Fallow & 100 & 0.01 & 2 \\
\hline 15 & Lentil-B.Aman & 70 & 0.01 & 1 \\
\hline 16 & Vegetab-Fallow-Blackgram & 70 & 0.01 & 2 \\
\hline 17 & Lentil-Aus- T. Aman & 60 & 0.01 & 2 \\
\hline \multirow[t]{2}{*}{$18-25$} & Other eight patterns (in Table 7) & 130 & 0.02 & \\
\hline & Total pulses and oil-seed crops & 8390 & 1.08 & \\
\hline
\end{tabular}

(chilli, onion, garlic, coriander) are included in this list. The most contributing cropping pattern is Vegetable-Fallow-T. Aman covering $2 \%$ of NCA which distributed in 23 upazilas. The second one is Vegetable-Aus- T. Aman covering over $1.18 \%$ of NCA and it is available in 19 upazilas out of 38 upazilas. Vegetables like colocasia, okra, amaranthus, brinjal, cucurbits, etc are grown in medium upland adjacent to rice fields during the rainy season and potato, sweet gourd, cole crops, leafy vegetables etc are grown during the winter season in Tripura (Anup et al., 2015).

\section{Rare cropping patterns}

In the present investigation, 26cropping patterns have been identified as rare cropping patterns with a negligible area (5-30 ha) coverage with seldom existence (Table 7). These are location specific system and are limited in one or two upazilas of the region. Total area coverage of the 26 patterns is only $0.048 \%$ of NCA. Among 
Table 6. Cropping patterns with vegetables and spices crops in Sylhet region, 2014-15.

\begin{tabular}{|c|c|c|c|c|}
\hline & Cropping pattern & Area (ha) & $\%$ of NCA & Frequency (no. of upazila) \\
\hline 01 & Vegetab-Fallow- T. Aman & 15495 & 2.00 & 23 \\
\hline 02 & Vegetab-Aus- T. Aman & 9130 & 1.18 & 19 \\
\hline 03 & Vegetab-Vegetab-Fallow & 5890 & 0.76 & 19 \\
\hline 04 & Vegetab-Vegetab- T. Aman & 5780 & 0.75 & 13 \\
\hline 05 & Vegetab-Vegetab-Vegetab & 5395 & 0.70 & 16 \\
\hline 06 & Vegetab-Fallow-Fallow & 5370 & 0.69 & 14 \\
\hline 07 & Fallow-Vegetab- T. Aman & 2470 & 0.32 & 9 \\
\hline 08 & Potato-Aus- T. Aman & 2170 & 0.28 & 11 \\
\hline 09 & Vegetab-Aus-Fallow & 1980 & 0.26 & 4 \\
\hline 10 & Potato-Fallow- T. Aman & 1570 & 0.20 & 15 \\
\hline 11 & Vegetab-Groundnut- T. Aman & 800 & 0.10 & 1 \\
\hline 12 & Chilli-Fallow-Fallow & 735 & 0.10 & 10 \\
\hline 13 & Chilli-Fallow- T. Aman & 500 & 0.06 & 8 \\
\hline 14 & S.Potato-Fallow- T. Aman & 475 & 0.06 & 10 \\
\hline 15 & Potato-Vegetab- T. Aman & 380 & 0.05 & 3 \\
\hline 16 & Chilli-Aus- T. Aman & 300 & 0.04 & 6 \\
\hline 17 & Coriander-Fallow- T. Aman & 275 & 0.04 & 6 \\
\hline 18 & Coriander-Fallow-Fallow & 265 & 0.03 & 7 \\
\hline 19 & Chilli-Aus-Fallow & 240 & 0.03 & 2 \\
\hline 20 & Vegetab-B.Aman & 200 & 0.03 & 1 \\
\hline 21 & S.Potato-Fallow-Fallow & 180 & 0.02 & 4 \\
\hline 22 & Potato-Jute-Fallow & 150 & 0.02 & 1 \\
\hline 23 & Potato-Jute- T. Aman & 150 & 0.02 & 1 \\
\hline 24 & Coriander-B.Aman & 120 & 0.02 & 1 \\
\hline 25 & Potato-Boro-Fallow & 100 & 0.01 & 1 \\
\hline 26 & Chilli-B.Aman & 80 & 0.01 & 1 \\
\hline 27 & Potato-B.Aman & 70 & 0.01 & 1 \\
\hline 28 & Vegetab-Fallow-Blackgram & 70 & 0.01 & 2 \\
\hline 29 & Coriander-Vegetab-Fallow & 60 & 0.01 & 3 \\
\hline 30 & Chilli-Vegetab-Fallow & 55 & 0.01 & 5 \\
\hline 31 & Potato-Aus-Fallow & 50 & 0.01 & 1 \\
\hline 32 & Wheat-Vegetab-Vegetab & 50 & 0.01 & 1 \\
\hline 33 & Wheat-Vegetab- T. Aman & 40 & 0.01 & 2 \\
\hline \multirow[t]{2}{*}{$34-51$} & Other 18 patterns (in Table 7) & 215 & 0.03 & - \\
\hline & Total vegetab and spices crops & 60810 & 7.86 & \\
\hline
\end{tabular}

these, the top three patterns viz Onion-Aus- T. Aman, Sweet potato-B.Aman and Wheat-JuteFallow were holding the same area i.e. 30 ha for each in Kamalganj, Biswambarpur, Lakhai and Tahirpur. The smallest area was recorded for nine cropping patterns whose coverage was only five hectares for each.

\section{Most dominant cropping pattern}

Boro-Fallow-Fallow was the most dominant cropping pattern in Sylhet region. It covers $39.64 \%$ of NCA in the region and is available in 36 upazilas out of 38 upazilas (Table 8). The highest area under this cropping was recorded
29,500 ha in Dharampasha upazila which represents $9.68 \%$ of the total Boro-FallowFallow area of the region and the lowest covered area was found in Kamalganj upazila. This pattern is frequent and concurrently experienced by early flash at in April and cold injury at reproductive stage. Diversified cropping pattern may be a resort for the farmer as a coping strategy with flood-related risk (Mandal and Bezbaruah, 2013) but scope of diversification is limited due to situational, environmental and climatic condition (FAO, 1988). Farmers of eastern India remained confined to their traditionally perceived 
Table 7. Rare cropping patterns covering non-significant area in Sylhet region, 2014-15.

\begin{tabular}{|c|c|c|c|c|c|}
\hline & Cropping pattern & Area (ha) & $\%$ of NCA & Frequency & Upazila \\
\hline 01 & Onion-Aus- T. Aman & 30 & 0.004 & 2 & Kamalganj+Biswambarpur \\
\hline 02 & S.Potato-B.Aman & 30 & 0.004 & 1 & Lakhai \\
\hline 03 & Wheat-Jute-Fallow & 30 & 0.004 & 1 & Tahirpur \\
\hline 04 & Grasspea-B.Aman & 25 & 0.003 & 1 & Madabpur \\
\hline 05 & Boro-Fallow-Blackgram & 20 & 0.003 & 2 & Dowarabazar+Companiganj \\
\hline 06 & Lentil-Vegetab-Vegetab & 20 & 0.003 & 1 & Rajnagar \\
\hline 07 & Maize-Fallow- T. Aman & 20 & 0.003 & 2 & Biswambarpur+Jagannathpur \\
\hline 08 & Potato-Sesame-Aus & 20 & 0.003 & 1 & Barlekha \\
\hline 09 & Garlic-Aus- T. Aman & 15 & 0.002 & 1 & Biswambarpur \\
\hline 10 & Grasspea-Fallow- T. Aman & 15 & 0.002 & 2 & Barlekha+Rajnagar \\
\hline 11 & Potato-Sesame- T. Aman & 15 & 0.002 & 2 & Barlekha+Kamalganj \\
\hline 12 & Garlic-Jute-Fallow & 10 & 0.001 & 1 & Golapganj \\
\hline 13 & Onion-B.Aman & 10 & 0.001 & 1 & Lakhai \\
\hline 14 & Onion-Jute-Fallow & 10 & 0.001 & 1 & Golapganj \\
\hline 15 & Onion-Jute- T. Aman & 10 & 0.001 & 1 & Lakhai \\
\hline 16 & Potato-Mungbean- T. Aman & 10 & 0.001 & 1 & Kamalganj \\
\hline 17 & W.Melon-Aus- T. Aman & 10 & 0.001 & 1 & Kamalganj \\
\hline 18 & Chilli-Vegetab- T. Aman & 5 & 0.001 & 1 & Companiganj \\
\hline 19 & Garlic-Fallow-Fallow & 5 & 0.001 & 1 & Dowarabazar \\
\hline 20 & Garlic-Fallow- T. Aman & 5 & 0.001 & 1 & Dowarabazar \\
\hline 21 & Garlic-Vegetab-Vegetab & 5 & 0.001 & 1 & Dowarabazar \\
\hline 22 & Lentil-Fallow- T. Aman & 5 & 0.001 & 1 & Barlekha \\
\hline 23 & Maize-Aus-Fallow & 5 & 0.001 & 1 & Companiganj \\
\hline 24 & Onion-Fallow- T. Aman & 5 & 0.001 & 1 & Dowarabazar \\
\hline 25 & Onion-Vegtab-Vegetab & 5 & 0.001 & 1 & Dowarabazar \\
\hline \multirow[t]{2}{*}{26} & Vegetab-Jute- T. Aman & 5 & 0.001 & 1 & Dowarabazar \\
\hline & Total & 345 & 0.048 & & - \\
\hline
\end{tabular}

farming system i.e. low productive monocropped farming (Sasmal, 2015). In the countrywide compilation of data, it was observed that the single Boro was the $2^{\text {nd }}$ dominant cropping pattern in Bangladesh covering 1.14 million ha (13\% of NCA in the country) with its distribution in 342 upazilas of 59 districts (Nasim et al., 2017).

\section{Second dominant cropping pattern}

The second dominant cropping pattern in Sylhet region is Boro-Fallow-T. Aman. It belongs to $15.74 \%$ of NCA of the region and spread over 37 upazilas (Table 9). Sunamganj sadar upazila of Sunamganj district holds the highest area of 7,000 ha under the Boro-Fallow- T. Aman cropping pattern. In the country-wide compilation of data, it was observed that Boro-F-T. Aman was the most dominant cropping pattern in Bangladesh covering 2.31 million ha (27\% of NCA in the country) with its distribution in 426 upazilas of 63 districts (Nasim et al., 2017).

\section{Third dominant cropping pattern}

Single T. Aman cropping pattern holds the third largest area coverage 117,560 hectares in Sylhet region. This area is $15.29 \%$ of NCA in the region and is distributed over 30 upazilas. Maulvibazar upazila occupied highest area of 8,700 ha for single T. Aman pattern which stands for $7.40 \%$ areaof this pattern in the region and lowest area (170 ha) for the same pattern was observed in Sreemangal upazila (Table 10). It was observed that the single T. Aman was the third dominant cropping pattern in Bangladesh covering 5.09 lac ha (6\% of NCA in the country) with its distribution in 162 upazilas of 36 districts (Nasim et al., 2017). 
Table 8. Distribution of the most dominant Boro-Fallow-Fallow cropping patterns in Sylhet region, $2014-15$.

\begin{tabular}{|c|c|c|c|c|}
\hline & Upazila & Area (ha) & $\%$ of upazila NCA & $\%$ of the pattern in region \\
\hline 01 & Dharampasha & 29500 & 83.10 & 9.68 \\
\hline 02 & Derai & 27100 & 87.99 & 8.89 \\
\hline 03 & Jamalganj & 21000 & 81.68 & 6.89 \\
\hline 04 & Sunamganj South & 19900 & 85.74 & 6.53 \\
\hline 05 & Baniachang & 19200 & 51.20 & 6.30 \\
\hline 06 & Jagannathpur & 18600 & 67.56 & 6.10 \\
\hline 07 & Sulla & 16200 & 69.53 & 5.31 \\
\hline 08 & Tahirpur & 14000 & 61.08 & 4.59 \\
\hline 09 & Nabiganj & 11000 & 43.98 & 3.61 \\
\hline 10 & Chhatak & 10000 & 50.23 & 3.28 \\
\hline 11 & Ajmiriganj & 9100 & 58.71 & 2.99 \\
\hline 12 & Dowarabazar & 8800 & 38.99 & 2.89 \\
\hline 13 & Sunamganj & 8500 & 44.95 & 2.79 \\
\hline 14 & Balaganj & 8200 & 29.66 & 2.69 \\
\hline 15 & Biswambarpur & 8000 & 46.92 & 2.62 \\
\hline 16 & Lakhai & 7600 & 49.00 & 2.49 \\
\hline 17 & Companiganj & 7500 & 40.09 & 2.46 \\
\hline 18 & Maulvibazar & 6000 & 23.47 & 1.97 \\
\hline 19 & Rajnagar & 6000 & 29.56 & 1.97 \\
\hline 20 & Bahubal & 5000 & 30.40 & 1.64 \\
\hline 21 & Jaintapur & 4500 & 31.06 & 1.48 \\
\hline 22 & Habiganj & 4000 & 20.27 & 1.31 \\
\hline 23 & Goainghat & 4000 & 16.80 & 1.31 \\
\hline 24 & Kulaura & 3600 & 16.06 & 1.18 \\
\hline 25 & Fenchuganj & 3600 & 42.35 & 1.18 \\
\hline 26 & Biswanath & 3500 & 21.15 & 1.15 \\
\hline 27 & Sreemangal & 3400 & 17.99 & 1.12 \\
\hline 28 & Baanibazar & 3400 & 24.37 & 1.12 \\
\hline 29 & Surma & 2500 & 16.61 & 0.82 \\
\hline 30 & Golapganj & 2300 & 13.76 & 0.75 \\
\hline 31 & Barlekha & 2100 & 18.03 & 0.69 \\
\hline 32 & Sylhet & 1750 & 14.94 & 0.57 \\
\hline 33 & Juri & 1700 & 16.08 & 0.56 \\
\hline 34 & Zakiganj & 1700 & 8.58 & 0.56 \\
\hline 35 & Kanaighat & 1500 & 6.46 & 0.49 \\
\hline \multirow[t]{2}{*}{36} & Kamalganj & 50 & 0.28 & 0.02 \\
\hline & Sylhet region & 304800 & 39.14 & 100.00 \\
\hline
\end{tabular}

\section{Fourth dominant cropping pattern}

Fourth dominant cropping pattern FallowAus- T. Aman has occupied 97,055 hectares representing $12.62 \%$ share of NCA in Sylhet region (Table11). This pattern is distributed over 29 upazilas where Chunarughat ranked in top position. This upazila has 10,500 ha area under Fallow-Aus-T. Aman which is only $46.44 \%$ of upazila NCA. Kamalganj upazila ranks in the second position with 8,800 ha area for this pattern, however, this upazila has allotted the biggest share $(48.70 \%)$ of its NCA. Aus-T. Aman pattern is almost common on high land and medium highland floodplain ridges soils (FAO, 1988).

\section{Fifth dominant cropping pattern}

Fifth dominant cropping pattern Boro-B. Aman had been covering 23,830 ha representing 3.10\% share of NCA in Sylhet region (Table 12). This 
Table 9. Distribution of the $2^{\text {nd }}$ dominant Boro-Fallow- T. Aman cropping pattern in Sylhet region, 2014-15.

\begin{tabular}{|c|c|c|c|c|}
\hline & Upazila & Area (ha) & $\%$ of upazila NCA & $\%$ of the pattern in region \\
\hline 01 & Sunamganj & 7000 & 37.02 & 5.78 \\
\hline 02 & Tahirpur & 6000 & 26.18 & 4.96 \\
\hline 03 & Balaganj & 6000 & 21.70 & 4.96 \\
\hline 04 & Rajnagar & 5400 & 26.60 & 4.46 \\
\hline 05 & Sulla & 5400 & 23.18 & 4.46 \\
\hline 06 & Sreemangal & 5300 & 28.04 & 4.38 \\
\hline 07 & Biswambarpur & 5000 & 29.33 & 4.13 \\
\hline 08 & Companiganj & 5000 & 26.72 & 4.13 \\
\hline 09 & Dowarabazar & 4900 & 21.71 & 4.05 \\
\hline 10 & Golapganj & 4500 & 26.93 & 3.72 \\
\hline 11 & Maulvibazar & 4200 & 16.43 & 3.47 \\
\hline 12 & Madhabpur & 4000 & 24.78 & 3.31 \\
\hline 13 & Jamalganj & 3900 & 15.17 & 3.22 \\
\hline 14 & Kamalganj & 3600 & 19.92 & 2.97 \\
\hline 15 & Surma & 3500 & 23.26 & 2.89 \\
\hline 16 & Baniachang & 3000 & 8.00 & 2.48 \\
\hline 17 & Chunarughat & 3000 & 13.27 & 2.48 \\
\hline 18 & Juri & 3000 & 28.38 & 2.48 \\
\hline 19 & Biswanath & 3000 & 18.13 & 2.48 \\
\hline 20 & Goainghat & 3000 & 12.60 & 2.48 \\
\hline 21 & Sylhet & 2700 & 23.06 & 2.23 \\
\hline 22 & Habiganj & 2500 & 12.67 & 2.07 \\
\hline 23 & Dharampasha & 2500 & 7.04 & 2.07 \\
\hline 24 & Kanaighat & 2500 & 10.77 & 2.07 \\
\hline 25 & Baanibazar & 2400 & 17.20 & 1.98 \\
\hline 26 & Chhatak & 2200 & 11.05 & 1.82 \\
\hline 27 & Derai & 2200 & 7.14 & 1.82 \\
\hline 28 & Jagannathpur & 2100 & 7.63 & 1.74 \\
\hline 29 & Ajmiriganj & 2050 & 13.23 & 1.69 \\
\hline 30 & Barlekha & 2000 & 17.17 & 1.65 \\
\hline 31 & Nabiganj & 1900 & 7.60 & 1.57 \\
\hline 32 & Sunamganj South & 1900 & 8.19 & 1.57 \\
\hline 33 & Lakhai & 1620 & 10.44 & 1.34 \\
\hline 34 & Jaintapur & 1500 & 10.35 & 1.24 \\
\hline 35 & Kulaura & 1150 & 5.13 & 0.95 \\
\hline 36 & Bahubal & 1000 & 6.08 & 0.83 \\
\hline \multirow[t]{2}{*}{37} & Fenchuganj & 100 & 1.18 & 0.08 \\
\hline & Sylhet region & 121020 & 15.74 & 100.00 \\
\hline
\end{tabular}

pattern is distributed over 11 upazilas where Baniachang ranked in top position. This upazila had 9,300 ha area for Boro-B. Aman pattern which is $24.80 \%$ of upazila NCA. Companiganj and Kanaighat upazila had only nominal area coverage for this system.

\section{Sixth dominant cropping pattern}

Sixth dominant cropping pattern BoroAus- T. Aman had been covering 17,840 hectares representing $2.32 \%$ share of NCA in Sylhet region (Table 13) and distributed over 12 upazilas. Chunarughat ranked in top position with 5,500 ha area which is $24.33 \%$ of upazila NCA.

\section{Crop diversity and cropping intensity} Bio-diversity plays important role in a good production of food, fodder, fuel, medicinal plants, aromatic plants and non-timber produce along with ecosystem service and climate regulation service (Manju and Sharma, 2016). The higher number of available crops under cultivation in an area dictates its higher diversity. The number of cropping patterns is also a gross indicator of crop diversity. A total of 87 cropping patterns were identified in the whole 
Table 10. Distribution of the $3^{\text {rd }}$ dominant Fallow-Fallow- T. Aman cropping pattern in Sylhet region, $2014-15$.

\begin{tabular}{llccc}
\hline & Upazila & Area (ha) & \% of upazila NCA & \% of the pattern in region \\
\hline 01 & Maulvibazar & 8700 & 34.04 & 7.40 \\
02 & Kanaighat & 8500 & 36.62 & 7.23 \\
03 & Kulaura & 8400 & 37.47 & 7.15 \\
04 & Jaintapur & 8300 & 57.28 & 7.06 \\
05 & Goainghat & 8000 & 33.60 & 6.81 \\
06 & Nabiganj & 7780 & 31.11 & 6.62 \\
07 & Chhatak & 6000 & 35.19 & 5.10 \\
08 & Jagannathpur & 6000 & 26.58 & 5.10 \\
09 & Balaganj & 5700 & 20.61 & 4.85 \\
10 & Beanibazar & 5000 & 35.84 & 4.25 \\
11 & Zakiganj & 5000 & 25.24 & 4.25 \\
12 & Dowarabazar & 4700 & 15.26 & 4.00 \\
13 & Companiganj & 4500 & 24.05 & 3.83 \\
14 & Biswanath & 3800 & 22.96 & 3.23 \\
15 & Baniachang & 3500 & 9.33 & 2.98 \\
16 & Surma & 3500 & 23.26 & 2.98 \\
17 & Barlekha & 2700 & 23.18 & 2.30 \\
18 & Golapganj & 2400 & 14.36 & 2.04 \\
19 & Sunamganj & 2000 & 10.58 & 1.70 \\
20 & Kamalganj & 1800 & 9.96 & 1.53 \\
21 & Fenchuganj & 1800 & 21.18 & 1.53 \\
22 & Sylhet & 1750 & 14.94 & 1.49 \\
23 & Juri & 1650 & 15.61 & 1.40 \\
24 & Rajnagar & 1650 & 8.13 & 1.40 \\
25 & Dharampasha & 1100 & 5.52 & 0.94 \\
26 & Sunamganj South & 1100 & 4.74 & 0.94 \\
27 & Derai & 1000 & 2.82 & 0.85 \\
28 & Bahubal & 600 & 3.65 & 0.51 \\
29 & Chunarughat & 460 & 2.03 & 0.39 \\
30 & Sreemangal & 170 & 0.90 & 100.00 \\
\hline & Sylhet region & 117560 & & \\
\hline & & & & \\
\end{tabular}

area of Sylhet region under this investigation. The highest number of cropping patterns was 34 identified in Dowarabazar upazila and that was 32 in Barlekha and 25 in Companiganj (Table 14). The lowest number of cropping patterns was identified 4 in Sulla followed by 6 in Derai. Higher number of cropping patterns is generally related to higher crop diversity indices. The upazilas having the lower number of cropping patterns were related to either low land or waterlogging or both. Sulla and Derai upazila face both limitations. The lowest diversity index for cropping pattern was recorded 0.219 in Derai followed by 0.255 in Sunamganj south. In a study, Shahidullah et al. (2006) also found the lowest values for all the diversity and intensity parameters in the salt- affected area of greater Noakhali. The highest value of diversity index for cropping pattern was found 0.844 in Sylhet sadar upazila that was followed by 0.842 in Juri upazila. Cropping pattern diversification clearly helps farmers to raise their farm income and has significant implications for making farming a remunerative profession in the Tripura state of India (Mandal and Bezbaruah, 2013). Diversified cropping pattern is an important strategy to cope with risk and uncertainty associated with agriculture due to unusual climatic and biological factors (Shiyani and Pandya, 1998). Since the lowest CDI was reported 0.313 in Derai followed by 0.367 in Sunamganj south. The highest value of CDI was observed 0.923 in Madhabpur followed by 0.915 in Habiganj sadar upazila. 
Table 11. Distribution of the $4^{\text {th }}$ dominant Fallow-Aus- T. Aman cropping pattern in Sylhet region, $2014-15$.

\begin{tabular}{|c|c|c|c|c|}
\hline & Upazila & Area (ha) & $\%$ of upazila NCA & $\%$ of the pattern in region \\
\hline 01 & Chunarughat & 10500 & 46.44 & 10.82 \\
\hline 02 & Kamalganj & 8800 & 48.70 & 9.07 \\
\hline 03 & Sreemangal & 7700 & 40.74 & 7.93 \\
\hline 04 & Bahubal & 6000 & 36.47 & 6.18 \\
\hline 05 & Kulaura & 5600 & 24.98 & 5.77 \\
\hline 06 & Habiganj & 5000 & 25.34 & 5.15 \\
\hline 07 & Kanaighat & 5000 & 21.54 & 5.15 \\
\hline 08 & Rajnagar & 4700 & 23.15 & 4.84 \\
\hline 09 & Jaintapur & 4500 & 31.06 & 4.64 \\
\hline 10 & Golapganj & 4200 & 25.13 & 4.33 \\
\hline 11 & Maulvibazar & 3700 & 14.48 & 3.81 \\
\hline 12 & Biswanath & 3600 & 21.75 & 3.71 \\
\hline 13 & Goainghat & 3500 & 14.70 & 3.61 \\
\hline 14 & Zakiganj & 3500 & 17.67 & 3.61 \\
\hline 15 & Surma & 3000 & 19.93 & 3.09 \\
\hline 16 & Balaganj & 2750 & 9.95 & 2.83 \\
\hline 17 & Sylhet & 2500 & 21.35 & 2.58 \\
\hline 18 & Dowarabazar & 2200 & 9.75 & 2.27 \\
\hline 19 & Barlekha & 2100 & 18.03 & 2.16 \\
\hline 20 & Fenchuganj & 2100 & 24.71 & 2.16 \\
\hline 21 & Madhabpur & 1400 & 8.67 & 1.44 \\
\hline 22 & Juri & 1300 & 12.30 & 1.34 \\
\hline 23 & Biswambarpur & 1100 & 6.45 & 1.13 \\
\hline 24 & Beanibazar & 900 & 6.45 & 0.93 \\
\hline 25 & Lakhai & 525 & 3.38 & 0.54 \\
\hline 26 & Nabiganj & 400 & 1.60 & 0.41 \\
\hline 27 & Sunamganj & 230 & 1.22 & 0.24 \\
\hline 28 & Chhatak & 200 & 1.00 & 0.21 \\
\hline \multirow[t]{2}{*}{29} & Companiganj & 50 & 0.27 & 0.05 \\
\hline & Sylhet region & 97055 & 12.62 & 100.00 \\
\hline
\end{tabular}

Table 12. Distribution of the $5^{\text {th }}$ dominant Boro-B. Aman cropping pattern in Sylhet region, 2014-15.

\begin{tabular}{llccc}
\hline & Upazila & Area (ha) & \% of upazila NCA & \% of the pattern in region \\
\hline 01 & Baniachang & 9300 & 24.80 & 39.03 \\
02 & Madhabpur & 3800 & 23.54 & 15.95 \\
03 & Nabiganj & 3300 & 13.19 & 13.85 \\
04 & Ajmiriganj & 2200 & 14.19 & 9.23 \\
05 & Lakhai & 2000 & 12.89 & 8.39 \\
06 & Rajnagar & 1000 & 4.93 & 4.20 \\
07 & Balaganj & 900 & 3.25 & 3.78 \\
08 & Habiganj & 800 & 4.05 & 3.36 \\
09 & Bahubal & 500 & 3.04 & 2.10 \\
10 & Companiganj & 20 & 0.11 & 0.08 \\
11 & Kanaighat & 10 & 0.04 & 0.04 \\
\hline & Sylhet region & 23830 & 3.10 & 100.00 \\
\hline
\end{tabular}


Table 13. Distribution of the $6^{\text {th }}$ dominant Boro-Aus- T. Aman cropping pattern in Sylhet region, $2014-15$.

\begin{tabular}{llrcc}
\hline & Upazila & Area (ha) & \% of upazila NCA & \% of the pattern in region \\
\hline 01 & Chunarughat & 5500 & 24.33 & 30.83 \\
02 & Habiganj & 4500 & 22.81 & 25.22 \\
03 & Madhabpur & 3400 & 21.07 & 19.06 \\
04 & Kulaura & 1600 & 7.14 & 8.97 \\
05 & Bahubal & 700 & 4.26 & 3.92 \\
06 & Juri & 500 & 4.73 & 2.80 \\
07 & Kamalganj & 490 & 2.71 & 2.75 \\
08 & Sreemangal & 350 & 1.85 & 1.96 \\
09 & Biswanath & 300 & 1.81 & 1.68 \\
10 & Jaintapur & 300 & 2.07 & 1.68 \\
11 & Nabiganj & 100 & 0.40 & 0.56 \\
12 & Maulvibazar & 100 & 0.39 & 0.56 \\
\hline & Sylhet region & 17840 & 2.32 & 100.00 \\
\hline
\end{tabular}

Hajjar et al. (2008) reported that genetic diversity of crop play an important role in enhancing the provision many services concurrently in multifunctional and sustainable agriculture through positive interactions or complementary functions. The range of cropping intensity values was recorded $107-233 \%$. The maximum value was for Chunarughat upazila of Habiganj district and minimum for Derai upazila of Sunamganj district. As a whole, the CDI of Sylhet region was calculated 0.877 and the average cropping intensity at the regional level was $148 \%$. In a simultaneous, the investigators identified 316 cropping patterns for whole Bangladesh; where the CDI value was 0.952 at the national level and the national average of cropping intensity was 200\% (Nasim et al., 2017). Diversified cropping pattern may enable the farmers compulsion of extracting the maximum possible utilization of land in the flood-free period (Mandal and Bezbaruah, 2013). Singh and Sidhu (2006) reported that a number of crops like sun hemp, cluster beans and sorghum had almost disappeared and there is reduced varietal diversification in rice and wheat. Crop diversification index of the wheatrice system has decreased from 0.75 in $1975-76$ to 0.58 in 2006-07 in Punjab though diversification forces pests to continuously relocate and recolonize their preferred host plants from year to year (Tscharntke et al., 2005, 2007).

\section{CONCLUSION}

Agricultural land is decreasing due to many factors and landscapes of Sylhet agricultural region are heterogeneous with the dominance of lowland. The cropping intensity of the Sylhet region was far lower (148\%) than the national average (192\%). The dominant cropping patterns were Boro-Fallow-Fallow, Boro-Fallow-T. Aman, Fallow-Fallow-T. Aman, Fallow-Aus-T Aman, Boro-B.Aman, Boro-Aus-T. Aman and Fallow-B.Aman in the region. Thus, overwhelming majority cropping patterns are consists of absolutely rice crop. The non-rice based cropping patterns were very few or area under those cropping patterns were much lower which are challenges to food and nutritional security for the people of the Sylhet region. Cropping patterns and crop diversity are also not up to the expected level. Based on the findings of the study, the following recommendations were made.

- Initiative has to be taken to increase the productivity of exclusive rice-based cropping pattern. As rice is the synonym of the primary food security, the high yielding stress tolerant varieties of rice along with recommended crop management packages to be adopted. Vegetable cultivation through the raised bed or floating method also needs to adopt in the suitable wetland area of this region. 
Table 14. Crop diversity and cropping intensity in Sylhet region, 2014-15.

\begin{tabular}{|c|c|c|c|c|c|c|}
\hline & Upazila & $\begin{array}{l}\text { No. of identified } \\
\text { pattern }\end{array}$ & $\begin{array}{l}\text { No. of } \\
\text { crop }\end{array}$ & $\begin{array}{l}\text { Diversity index for } \\
\text { cropping pattern }\end{array}$ & $\begin{array}{l}\text { Crop diversity } \\
\text { index (CDI) }\end{array}$ & C.I. $(\%)$ \\
\hline 01 & Ajmiriganj & 07 & 06 & 0.607 & 0.741 & 130 \\
\hline 02 & Bahubal & 14 & 08 & 0.746 & 0.861 & 172 \\
\hline 03 & Baniachang & 11 & 09 & 0.659 & 0.784 & 139 \\
\hline 04 & Chunarughat & 07 & 06 & 0.693 & 0.876 & 233 \\
\hline 05 & Habiganj & 15 & 14 & 0.817 & 0.915 & 211 \\
\hline 06 & Lakhai & 21 & 16 & 0.711 & 0.843 & 147 \\
\hline 07 & Madhabpur & 15 & 12 & 0.823 & 0.923 & 229 \\
\hline 08 & Nabiganj & 17 & 12 & 0.686 & 0.780 & 125 \\
\hline 09 & Barlekha & 32 & 16 & 0.836 & 0.910 & 157 \\
\hline 10 & Juri & 16 & 10 & 0.842 & 0.913 & 176 \\
\hline 11 & Kamalganj & 22 & 18 & 0.688 & 0.853 & 200 \\
\hline 12 & Kulaura & 09 & 07 & 0.779 & 0.873 & 160 \\
\hline 13 & Maulvibazar & 09 & 06 & 0.775 & 0.866 & 143 \\
\hline 14 & Rajnagar & 16 & 12 & 0.776 & 0.862 & 161 \\
\hline 15 & Sreemangal & 13 & 10 & 0.706 & 0.847 & 188 \\
\hline 16 & Biswambarpur & 20 & 20 & 0.676 & 0.819 & 153 \\
\hline 17 & Chhatak & 08 & 05 & 0.642 & 0.724 & 117 \\
\hline 18 & Dharampasha & 14 & 12 & 0.298 & 0.446 & 114 \\
\hline 19 & Derai & 06 & 05 & 0.219 & 0.313 & 107 \\
\hline 20 & Dowarabazar & 34 & 25 & 0.745 & 0.846 & 144 \\
\hline 21 & Jagannathpur & 11 & 11 & 0.486 & 0.585 & 112 \\
\hline 22 & Jamalganj & 09 & 09 & 0.309 & 0.469 & 117 \\
\hline 23 & Sulla & 04 & 03 & 0.460 & 0.623 & 126 \\
\hline 24 & Sunamganj South & 07 & 06 & 0.255 & 0.367 & 109 \\
\hline 25 & Sunamganj & 09 & 08 & 0.647 & 0.682 & 149 \\
\hline 26 & Tahirpur & 12 & 11 & 0.552 & 0.719 & 136 \\
\hline 27 & Balaganj & 10 & 07 & 0.806 & 0.889 & 153 \\
\hline 28 & Beanibazar & 08 & 06 & 0.770 & 0.848 & 134 \\
\hline 29 & Biswanath & 08 & 06 & 0.814 & 0.894 & 163 \\
\hline 30 & Companiganj & 25 & 12 & 0.708 & 0.808 & 138 \\
\hline 31 & Fenchuganj & 08 & 07 & 0.712 & 0.806 & 138 \\
\hline 32 & Goainghat & 08 & 08 & 0.802 & 0.883 & 144 \\
\hline 33 & Golapganj & 15 & 13 & 0.811 & 0.884 & 172 \\
\hline 34 & Jaintapur & 15 & 10 & 0.763 & 0.873 & 148 \\
\hline 35 & Zakiganj & 11 & 09 & 0.716 & 0.806 & 133 \\
\hline 36 & Kanaighat & 13 & 10 & 0.787 & 0.878 & 154 \\
\hline 37 & Surma & 08 & 07 & 0.814 & 0.879 & 157 \\
\hline \multirow[t]{2}{*}{38} & Sylhetsadar & 13 & 08 & 0.844 & 0.912 & 178 \\
\hline & Sylhet region & 87 & 29 & 0.778 & 0.877 & 148 \\
\hline
\end{tabular}


- Overwhelming majority cropping patterns are consist of either single rice/double rice/triple rice crop. To enhancing the existing productivity of these rice-cropping patterns, adoption of high yielding varieties along with the integration of other suitable crops, livestock, fisheries and management technologies for the judicious and efficient use of on-farm resources are essential to sustain the productivity, soil health and enhance the carrying capacity of the ecosystem.

- The upazilas having higher cropping pattern index might be studied in depth to extrapolate potential cropping patterns to other upazilas of similar environments.

- Research and development programmes can be taken in hand to diversify the single and double-cropped cropping pattern with the inclusion of appropriate new crops, crop varieties and non-crop species.

\section{REFERENCES}

Anup Das, G I Ramkrishna, G S Yadav, JayantaLayek, C Debnath, B U Choudhury, K P Mohaptara, S V Ngachan and Supriya Das. 2015. Capturing traditional practices of rice based farming systems and identifying interventions for resource conservation and food security in Tripura, India. Applied Ecology and Environmental Sciences, 4: 100-107.

Banglapedia (2004). National Encyclopedia of Bangladesh. Dhaka: Asiatic Society of Bangladesh.

BBS (Bangladesh Bureau of Statistics). 2011. Agricultural Census of Bangladesh. Dhaka: Ministry of Planning, Government of the People's Republic of Bangladesh.

BBS (Bangladesh Bureau of Statistics). 2014. Statistical Yearbook of Bangladesh. Statistics Division, Ministry of Planning, Government of the People's Republic of Bangladesh.

BBS (Bangladesh Bureau of Statistics). 2016. Statistical Yearbook of Bangladesh. Statistics Division, Ministry of Planning, Government of the People's Republic of Bangladesh.

BBS (Bangladesh Bureau of Statistics). 2017. Statistical Yearbook of Bangladesh. Statistics Division, Ministry of Planning, Government of the People's Republic of Bangladesh.

Borthakur, S K, T R Sarma, K K Nath, P Deka. 1998. The house gardens of Assam : a traditional Indian experience of management and conservation of biodiversity - I. Ethnobotany, 10:32 -37.

FAO (Food and agriculture Organization), 1988. Land resources of Bangladesh for Agricultural development (Report 2: Agro-ecological regions of Bangladesh). Rome, Italy.

Hajjar, R, D I Jarvis and B Gemmil-Herren. 2008. The utility of crop genetic diversity in maintaining ecosystem services. Agriculture, Ecosystems and Environment, 123:261-270.

Hasan, M N, M S Hossain, M A Bari, and M R Islam. 2013. Agricultural land availability in Bangladesh. SRDI, Dhaka, Bangladesh, 42 pp.

Jackson, B R, A Yantasast, C Prechachat, M A Chowdhury and S M H Zaman. 1972. Breeding rice for deep-water areas. Pages 517-528 In: International Rice Research Institute, Rice Breeding, LosBaños, Philippines.

Kshirsagar, K G, S Pandey and M R Bellon. 1997. Farmers' Perception, Varietal Characteristics and Technology Adoption: The Case of Rainfed Village in Eastern India. Discussion paper5/97. Social Sciences Division, IRRI, Philippines.

Mandal, R and M P Bezbaruah. 2013. Diversification of Cropping Pattern: Its Determinants and Role in Flood Affected Agriculture of Assam Plains. Indian J. Agric. Econ. 68(2): 169-181.

Manju Sundriyal and Bhavtosh Sharma. 2016. Status of biodiversity in central Himalaya. Applied Ecology and Environmental Sciences, 4(2): 37-43.

Martin, J H and W H Leonard. 1953. Principles of Field Crop Production. McMillan Company, New York.

Nasim, M, S M Shahidullah, A Saha, M A Muttaleb, T L Aditya, M A Ali and M S Kabir. 2017. Distribution of Crops and Cropping Patterns in Bangladesh. Bangladesh Rice J. 21(2): 1-55.

Rahman, M T and M N Hasan. 2003. Assessment of Shifting of Agricultural Land to Non-Agricultural Land in Bangladesh, SRDI, Ministry of Agriculture, Dhaka.

Sasmal, T K. 2015. Adoption of New Agricultural Technologies for Sustainable Agriculture in Eastern India: An Empirical Study. Indian Res. J. Ext. Edu. 15 (2): 38-42.

Shahidullah, S M, M S A Talukder, M S Kabir, A H Khan and N E Elahi. 2006. Cropping patterns in the South East Coastal Region of Bangladesh. Journal of Agriculture and Rural Development, 4 (1\&2): 53-60.

Shirsath, P B, P K Aggarwal, P K Thornton and A Dunnett. 2017. Prioritizing Climate-Smart Agricultural Land Use Options at a Regional Scale. Agricultural Systems, 151:174-183. 
Shriar, A J. 2000. Agricultural Intensity and its Measurement in Frontier Regions. Agroforestry Systems, 49: 301-318.

Shiyani, R L and H R Pandya. 1998. Diversification of agriculture in Gujarat: A spatio-temporal analysis. Indian J. Agric. Econ. 53(4):627-639.

Singh, J and R S Sidhu. 2006. Accounting for Impact of Environmental Degradation in Agriculture of Indian Punjab. Agric. Economics Res. Rev. 19: 37-48.
Tscharntke, T, R Bommarco, Y Clough, T O Crist, D Klein, T A Rand, J M Tylianakis, S van Nouhuys, S Vidal. 2007. Conservation Biological Control and Enemy Diversity on a Landscape Scale. Biol. Control 43, 294-309.

Tscharntke, T, A M Klein, A Kruess, I Steffan-Dewenter, C Thies. 2005. Landscape Perspectives on Agricultural Intensification and Biodiversity-Ecosystem Service Management. Ecol. Lett. 8, 857-874.

\section{Appendix 1. List of cropping patterns in Sylhet region, 2014-15.}

\begin{tabular}{|c|c|c|c|c|c|}
\hline & Cropping pattern & Area (ha) & & Cropping pattern & Area (ha) \\
\hline 01 & Boro-Fallow-Fallow & 304800 & 32 & Wheat-Fallow- T. Aman & 325 \\
\hline 02 & Boro-Fallow- T. Aman & 121020 & 33 & Chilli-Aus- T. Aman & 300 \\
\hline 03 & Fallow-Fallow- T. Aman & 117560 & 34 & Coriander-Fallow- T. Aman & 275 \\
\hline 04 & Fallow-Aus- T. Aman & 97055 & 35 & Coriander-Fallow-Fallow & 265 \\
\hline 05 & Boro-B.Aman & 23830 & 36 & Chilli-Aus-Fallow & 240 \\
\hline 06 & Boro-Aus- T. Aman & 17840 & 37 & Fallow-Fallow-Blackgram & 200 \\
\hline 07 & Vegetab-Fallow- T. Aman & 15495 & 38 & Mustard-Jute- T. Aman & 200 \\
\hline 08 & Fallow-B.Aman & 10140 & 39 & Vegetab-B.Aman & 200 \\
\hline 09 & Vegetab-Aus- T. Aman & 9130 & 40 & S.Potato-Fallow-Fallow & 180 \\
\hline 10 & Vegetab-Vegetab-Fallow & 5890 & 41 & W.Melon-Fallow- T. Aman & 170 \\
\hline 11 & Vegetab-Vegetab- T. Aman & 5780 & 42 & Potato-Jute-Fallow & 150 \\
\hline 12 & Vegetab-Vegetab-Vegetab & 5395 & 43 & Potato-Jute- T. Aman & 150 \\
\hline 13 & Vegetab-Fallow-Fallow & 5370 & 44 & Wheat-Aus- T. Aman & 150 \\
\hline 14 & Mustard-B.Aman & 2690 & 45 & Mustard-Aus-Fallow & 140 \\
\hline 15 & Fallow-Vegetab- T. Aman & 2470 & 46 & Coriander-B.Aman & 120 \\
\hline 16 & Potato-Aus- T. Aman & 2170 & 47 & Groundnut-Fallow-Fallow & 115 \\
\hline 17 & Vegetab-Aus-Fallow & 1980 & 48 & Blackgram-B.Aman & 110 \\
\hline 18 & Boro-Aus-Fallow & 1600 & 49 & Lentil-Jute- T. Aman & 100 \\
\hline 19 & Potato-Fallow- T. Aman & 1570 & 50 & Mustard-Fallow-Fallow & 100 \\
\hline 20 & Groundnut-Fallow- T. Aman & 1245 & 51 & Potato-Boro-Fallow & 100 \\
\hline 21 & Mustard-Fallow- T. Aman & 950 & 52 & Chilli-B.Aman & 80 \\
\hline 22 & Fallow-Jute- T. Aman & 890 & 53 & Lentil-B.Aman & 70 \\
\hline 23 & Vegetab-Groundnut- T. Aman & 800 & 54 & Potato-B.Aman & 70 \\
\hline 24 & Chilli-Fallow-Fallow & 735 & 55 & Vegetab-Fallow-Blackgram & 70 \\
\hline 25 & Mustard-Boro- T. Aman & 560 & 56 & Coriander-Vegetab-Fallow & 60 \\
\hline 26 & Mustard-Aus- T. Aman & 510 & 57 & Lentil-Aus- T. Aman & 60 \\
\hline 27 & Chilli-Fallow- T. Aman & 500 & 58 & Chilli-Vegetab-Fallow & 55 \\
\hline 28 & S.Potato-Fallow- T. Aman & 475 & 59 & Potato-Aus-Fallow & 50 \\
\hline 29 & Wheat-B.Aman & 435 & 60 & Wheat-Vegetab-Vegetab & 50 \\
\hline 30 & Potato-Vegetab- T. Aman & 380 & 61 & Wheat-Vegetab- T. Aman & 40 \\
\hline 31 & Mustard-Boro-Fallow & 340 & $62-87$ & Other 26 patterns (Table 7) & 345 \\
\hline
\end{tabular}

